\title{
Is Nasogastric Tube essential in abdominal surgeries? Randomized controlled trail.
}

1. MBBS, FCPS

District Surgeon General Surgery DHQ Charsadda.

2. MBBS, MCPS (General Surgery), FCPS (General Surgery), FCPS (Thoracic Surgery) Associate Professor LRH Peshawar.

3. MBBS, FCPS (General Surgery) Consultant Surgeon General Surgery DHQ Charsadda.

4. MBBS, FCPS (General Surgery) Medical Officer General Surgery DHQ Charsadda.

Correspondence Address:

Dr. Viqar Aslam

LRH Peshawar.

bilalsurg@gmail.com

Article received on: 06/04/2020

Accepted for publication: $12 / 02 / 2021$

\section{Muhammad Bilal ${ }^{1}$, Viqar Aslam², Zaheer ud din ${ }^{3}$, Waqas Jan ${ }^{4}$}

ABSTRACT... Objective: To compare mean hospital stay in patients with abdominal surgeries with and without Nasogastric tube. Study Design: Randomized Controlled Trail study. Setting: DHQ Charsadda. Period: Jan to Nov 2018. Material \& Methods: One hundred and thirty two patients who underwent abdominal surgeries according to a preset inclusion criteria were in this study. These Patients were randomly assigned using sealed opaque envelopes containing computer-generated random numbers into with and without NG tube. Mean hospital stay was noted in both groups. Student ' $t$ ' test was used to compare the mean hospital stay of both groups. Results: Mean age of patients in group A was $28.50 \pm 9.28$ years and for group $B$ was $30.12+9.09$ years. Mean hospital stay for group A was $5.64+2.32$ days and for group B was $8.73+\overline{3} .43$ days with a p-value of $<0.000$. Conclusion: Patient with nasogastric tube stay longer in hospital than without tube.

Key words: $\quad$ Abdominal Distension, Hospital Stay, Nasogastric Tube.

Article Citation: Bilal M, Aslam V, Zaheer ud din, Jan W. Is Nasogastric Tube essential in abdominal surgeries? Randomized controlled trail. Professional Med J 2021; 28(10):1397-1400. https://doi.org/10.29309/TPMJ/2021.28.10.4701

\section{INTRODUCTION}

Levin in 1921 introduced nasogastric tube (NGT) in general surgery. It was made to feed sick patients who are unable to consume an appropriate nourished diet after surgical procedures. Air swallowed in these patients can cause post abdominal distension thus it is prevented by the use of NGT decompression and that is why it become the part of surgical management in early $20^{\text {th }}$ century with advancement of aseptic technique, general anesthesia and encouraging success in major abdominal surgeries preventing postoperative nausea, vomiting and other wound healing complications. It aims to hasten the return of bowel movement, prevent pulmonary complications, risk of anastomotic leakage and increase patients comfort and diminish. Until 1963 when Garber noted that routine NGT decompression was pointless and is one of the most painful procedure performed in medicine and is associated with complications like sinusitis, nasolaryngeal and vocal cords trauma, gastroesohageal reflux leading to aspiration pneumonia and electrolyte imbalance. ${ }^{1-5}$
The objective of this study was to compare average or mean hospital stay in recovery of patients with abdominal surgeries with nasogastric tube or without nasogastric tube placement in local population to observe the demographic variability.

\section{MATERIAL \& METHODS}

This RCT study was approved by the Ethics Committee of the institution (1098-1100/DHQ Hospital.CHD). Eligible patients were randomly assigned using sealed opaque envelopes containing computer-generated random numbers into two groups: the managed with placement of NGT postoperatively or without NGT postoperatively. Figure-1 among these subjects 66 participants were managed through NGT postoperatively while in other 66 patient's recovery was seen without placement of NGT. Patients suffering from chronic diseases i.e. diabetes mellitus and severe complications i.e. anal fistulas were excluded from the study. This study was conducted in surgical unit of local teaching hospital (DHQ Charsadda) from January 2018 till November 2018 in which overall 
132 participants with different abdominal surgical procedures were included directly from outpatient department by lottery method.

Postoperative recovery was considered when bowel movements returned and patients pass first flatus after the surgery, it was recorded by the on duty doctor. Overall mean stay in hospital in both groups was recorded in hours. The data was entered in SPSS 23 where results were analyzed according to frequencies and percentages among variable categories. Student 't' test was used to compare the mean hospital stay of both groups and $p$-value $\leq 0.05$ was considered as significant.

\section{RESULTS}

Total number of participants were 132 (100\%) out of which 90 (68\%) were males and 42 (32\%) were females; they were divided into two groups. Group A recovered without NGT placement while in group B patients were managed with placement of NGT Age distribution for participants, Mean age of patients in group $A$ was $28.50 \pm 9.28$ years and for group B was 30.12+_9.09 years it was concluded that majority of patients 53 (44.16\%) were between 31 to 40 years of age. (Table-I)

Mean hospital stay was recorded for each group in days, for group A mean hospital stay was equal to $5.64+2.32$ days and for group $B$ it was $8.73+3.43$ days with a $p$-value of $<0.000$. (Table-II) There was also significance difference in length of stay in both groups regarding gender with a $p$ value 0.000 . (Table-III)

\section{DISCUSSION}

NGT placement is achieved by prophylaxis gastric decompression, a decrease in episodes of vomit and nausea, a decrease in distension and pulmonary aspiration, decrease in chances of wound separation and infection and decrease risk for dehiscence and hernia.

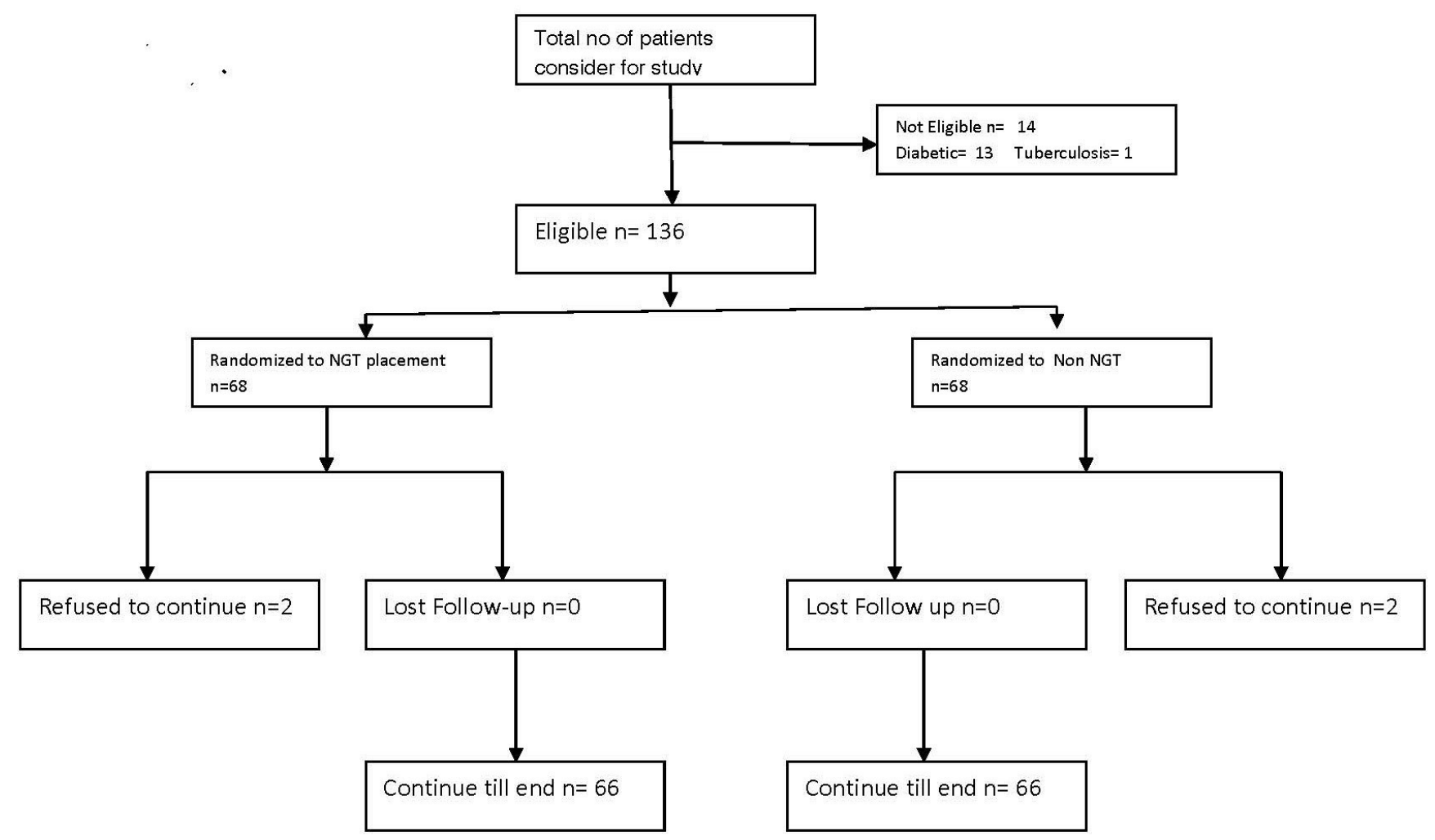

Figure-1. Flow chart. 


\begin{tabular}{|c|c|c|c|c|c|}
\hline \multirow{2}{*}{ Group } & \multicolumn{4}{|c|}{ Age } & \multirow{2}{*}{ Total } \\
\hline & 20-30 Years & 31-40 Years & 41-50 Years & 51-60 Years & \\
\hline A & 19 (28.78\%) & $28(42.42 \%)$ & 15 (22.72\%) & $4(6.06 \%)$ & $66(100 \%)$ \\
\hline B & 15 (22.72\%) & 25 (37.87\%) & 24 (36.36\%) & 2 (3.03\%) & $66(100 \%)$ \\
\hline Total & 34 (28.33\%) & 53 (44.16\%) & 39 (32.5\%) & $6(5 \%)$ & $66(100 \%)$ \\
\hline
\end{tabular}

\begin{tabular}{|l|c|c|c|c|c|}
\hline \multirow{2}{*}{ Age } & \multicolumn{9}{|c|}{ Hospital stay in days } & \multirow{2}{*}{ P-Value } \\
\hline & Mean & Group A & & Group B & \\
\hline 20-30 Years & 4.67 & SD & Mean & SD & 0.001 \\
\hline 31-40 Years & 5.34 & 1.13 & 7.68 & 3.54 & 0.000 \\
\hline $41-50$ Years & 5.21 & 2.17 & 8.45 & 3.28 & 0.000 \\
\hline $51-60$ Years & 4.93 & 1.97 & 8.75 & 3.24 & 0.001 \\
\hline
\end{tabular}

Table-II. Age wise comparison of hospital stay.

\begin{tabular}{|c|c|c|c|c|c|}
\hline \multirow{3}{*}{ Gender } & \multicolumn{4}{|c|}{ Hospital stay in days } & \multirow{3}{*}{ P-Value } \\
\hline & \multicolumn{2}{|c|}{ Group A } & \multicolumn{2}{|c|}{ Group B } & \\
\hline & Mean & SD & Mean & SD & \\
\hline Male & 5.04 & 2.34 & 8.02 & 3.02 & 0.000 \\
\hline Female & 5.52 & 2.56 & 8.65 & 3.79 & 0.002 \\
\hline
\end{tabular}

But the point to be considered is that what if the advantages are overruled by complications of this procedure i.e. pulmonary, electrolyte, mechanical and infectious problems. These problems along with the patients discomfort made us thought about whether to place NGT or not for minor or routine abdominal surgical procedures. With the passage of time advance surgical approaches have been introduced and good postoperative management along with fluid and electrolyte balance has raised questions on routine use of postoperative NGT. ${ }^{5-7}$

In our study age range was from 20 to 53 years with mean age of $28.52 \pm 9.48$ years. In group a mean age of participants was $28.50 \pm 9.28$ years while group B had $30.32 \pm 9.09$ years. Majority of the participants of the study were between 29 to 40 years of age in both groups. These results are very much similar to studies of Qureshi et $\mathrm{al}^{8}$ and Shamil et al. ${ }^{9}$ Khan $\mathrm{N}$ et $\mathrm{al}^{10}$ and Baraza et al ${ }^{11}$ had shown a larger mean age i.e. 35 years and 63 years respectively, as compared to this study and other previously described studies. This difference in mean age was due the inclusion of larger range of age. In this study, $68 \%$ were males and $38 \%$ were females with a ratio of $2.16: 1$. This male high proportion has also observed in other studies. ${ }^{11,12}$

Colvin et $\mathrm{al}^{12}$ and Wolf et $\mathrm{al}^{13}$ in has shown no difference in mean hospital stay of patients with or without NGT placement which is contrast to present findings. Clinical trial done by Khan $\mathrm{N}$ et al ${ }^{10}$ concluded the length of stay in hospital as $7.93 \pm 1.27$ days versus $6.54 \pm 0.85$ days in patients with and without nasogastric tube placement similar to our findings. Jottard el $\mathrm{al}^{7}$ has compared selective versus routine NGT decompression after elective laparotomy which does not support the idea of prophylactic use of NGT. Many patients' trails suggested that this practice does not provide any benefit but discomfort. It was also concluded by these studies that they lengthen the hospital stay had increased. ${ }^{7-9}$

\section{CONCLUSION}

It was concluded from our study that mean hospital 
stay of the patient is longer with nasogastric tube than without NG.

Copyright@ 12 Feb, 2021.

\section{REFERENCES}

1. Vinay HG, Raza M, Siddesh G. Elective bowel surgery with or without prophylactic nasogastric decompression: A prospective, randomized trial. J Surg Tech Case Rep. 2015; 7(2):37-41. doi:10.4103/2006-8808.185654.

2. You-Chen L, Pei-Ching S, Hsin-Hao C, Shu-Jung L, Hsingchu-Chu $\mathrm{C}$, Lee-Ching $\mathrm{H}$, et al. The application of lidocaine to alleviate the discomfort of nasogastric tube insertion. A systematic review and meta-analysis. 2018; 97:5 -9746.

3. Milsom SA, Sweeting JA, Sheahan $\mathrm{H}$, et al. Naso-enteric tube placement: A review of methods to confirm tip location, global applicability and requirements. World J Surg. 2015; 39:2243-52.

4. Kavakli AS, Ozturk NK, Karaveli A, Onuk AA, Ozyurek $\mathrm{L}$, Inanoglu K. Comparison of different methods of nasogastric tube insertion in anesthetized and intubated patients. Rev Bras Anestesiol. 2017; 67:6.

5. Mandal M, Karmakar A, Basu SR. Nasogastric tube insertion in anaesthetized, intubated adult patients: A comparison between three techniques. Indian $\mathrm{J}$ Anaesth 2018; 62:609.

6. Shlamovitz GZ, Kate V. Nasogastric intubation. Updated: Jul 17, 2018.
7. Jottard K, Hoff C, Maessen JC, Ramshorst BV, van Berlo CLH, Logeman F, et al. Life and death of the nasogastric tube in elective colonic surgery in the Netherlands. ClinNutr. 2009; 28:26-8.

8. Qureshi U, Hanif M, Zia N, Khan MM. Role of nasogastric intubation after small bowel anastomosis. J Coll Physicians Surg Pak. 2008; 19(6):354-8.

9. Shamil N, Quraishi S, Riaz S, Channa A, Maher M. Is nasogastric decompression necessary in elective enteric anastomosis? J Ayub Med Coll Abbottabad. 2010; 22(4):236.

10. Postoperative nasogastric decompression is not warranted in elective closure of gut stomas and bilioenteric anastomosis: A randomized controlled trial. JPMI. 2008; 22(3):219-24.

11. Baraza W, Wild J, Barber W, Brown S. Postoperative management after loop ileostomy closure: Are we keeping patients in hospital too long? Ann R CollSurg Engl. 2010; 92(1):51-5.

12. Colvin DB, Lee W, Eisenstat TE, Rubin RJ, Salvati EP. The role of nasogastric intubation in elective colonic surgery. Dis Colon Rectum. 1986; 29:295-9.

13. Wolff BG, Pembeton JH, van Heerden JA, Beart RW, Nivatvongs S, Devine RM, et al. Elective colon and rectal surgery without nasogastric decompression. Prospective randomized trial. Ann Surg. 1989; 209:670-3.

\begin{tabular}{|c|c|c|c|}
\hline \multicolumn{4}{|c|}{ AUTHORSHIP AND CONTRIBUTION DECLARATION } \\
\hline Sr. \# & Author(s) Full Name & Contribution to the paper & Author(s) Signature \\
\hline 2 & $\begin{array}{l}\text { Muhammad Bilal } \\
\text { Viqar Aslam } \\
\text { Zaheer ud din } \\
\text { Waqas Jan }\end{array}$ & $\begin{array}{l}\text { Data collection, Analysis, } \\
\text { Literature review. } \\
\text { Research designing, Literature } \\
\text { review and drafting. } \\
\text { Objective setting, Drafting. } \\
\text { Data collection, Paper write-up. }\end{array}$ & $\begin{array}{l}\text { Vashom } \\
\text { Eaheox } \\
\text { Wagas }\end{array}$ \\
\hline
\end{tabular}

